\title{
Analysis of fishing vessel safety policy in Lamongan In- donesia
}

\author{
Aris Sarjito * \\ Indonesian Defense University, Bogor, Indonesia
}

\author{
Keywords \\ Safety of fishing vessel \\ Seaworthiness of fishing vessel \\ Nationality Certificate of the Ship \\ Received: 6 February 2019 \\ Accepted: 7 March 2019 \\ Published: 24 April 2019
}

\begin{abstract}
This research highlights the completeness of fishing vessels' safety in Brondong, East Java, Indonesia. Brondong Nusantara Fisheries Port is one of the largest fishing ports in East Java, with 1,546 fishing vessels. Ironically, in the study, it was found that only $4 \%$ of all fishing vessels had vessel certificates that were still active. This study uses a qualitative analysis approach, which aims to describe and analyze the phenomena relating to the implementation of fishing vessel safety policies carried out by the Indonesian Minister of Transportation No. KM 46 of 1996 concerning Certification of the Sea Worthiness of Fishing Vessels, which requires that every Fishing Vessel meet the requirements of seaworthiness before sailing. This research is important because the lack of safety equipment for fishing vessels in Brondong has been going on for decades. There is almost no solution to this problem. The weak implementation of fishing vessel safety regulations in Brondong is due to weak law enforcement, lack of supervision from local authorities, and the weak purchasing power of boat owners for ship safety equipment.
\end{abstract}

(C) 2019 The Author(s). Published by TAF Publishing

\section{INTRODUCTION}

Fishing is one of the most dangerous activities. According to (Chan, Hamid, \& Mokhtar, 2016) in "A Theoretical Review of Human Errors in Maritime Accidents", "the most significant problems affecting cruise safety are collisions, fires, overturning and drowning. Maritime accidents result in loss of human life, loss of property, and pollution".

The number of shipping vessel accidents in Indonesia is quite alarming. In the National Transportation Safety Committee (NTSC) Database issued on November 25, 2016, the total number of shipping accidents during 2010-2016 was 54 times with details of sinking 12; burning 19; collision 17; ran aground 3; Other 2; which left 337 dead; and 474 injured.

From these data, it can be seen that safety factors are still not a priority for shipping agents in Indonesia.

Seaworthy certification of fishing vessels in fishing operations concerns the safety and security of all crew members. Ships granted permission to sail are ships that have fulfilled administrative feasibility and technical sailing feasibility issued by Syahbandar in the form of Sailing Permit (SIB) after previously fulfilling the Operation Acceptance Letter (SLO). The facts in almost every fishing port in Indonesia have two agencies that have the duty and authority to issue seaworthy certificates for ships to sail, namely the Ministry of Transportation (syahbandar general) and the Ministry of Maritime Affairs and Fisheries (syahbandar fisheries).

Both institutions have rights because they have a legal basis, as stipulated in the law. The existence of the same authority from the two relevant agencies resulted in confusion and overlapping roles of each Syahbandar which ultimately had an impact on fisheries actors, including the validity of certificates and swelling financing.

Brondong Nusantara Fisheries Port (NFP) has a strategic role in fisheries and marine development, namely as a centre or central for marine fisheries activities, especially those in the East Java Lamongan Regency.

There are 13,997 fishermen and no less than 1,546 fishing boat units, 435 fish cultivators, 49 hatchery entrepreneurs (7 fish storage units), and 7 ice plant units that provide fishermen's needs source (Food and Agriculture Organization, 2004). But with such great potential, ironically, there are

\footnotetext{
*corresponding author: Aris Sarjito
}

†email: arissarjito@gmail.com 
many fishing vessels that are very alarming. There are almost no fishing vessels equipped with safety equipment but still allowed to sail. Even though once sailing takes 10 days to 12 days. This is very dangerous because if an accident occurs, the fishermen must handle it themselves without safety equipment.

Equipment that should be added to fishing vessels to meet safety standards is: lifebuoy, lifejackets, life raft, first aid box, fire extinguishers, radar, lights and signals, Very High Frequency (VHF) radios, distress flares, compasses, watertight doors, and stairs.

Data obtained from the Department of Transportation of Lamongan District (2018) shows that only 7.8\% of 1,546-ship units in Brondong have sea-worthy fishing vessel/shipfitting certificates. This needs to get serious attention from the government, considering that fishing vessels that sail without a boat mean that besides the illegal conditions, the condition of the ship is not known as the safety equipment that should be on board. So that if an accident occurs at sea, then it cannot be overcome immediately.

The issue of shipping safety on fishing vessels is very complex because it involves operators, the supervision of officials, and fishermen. The operator should be responsible for the completeness of the safety of the ship which is marked with a certificate/ship pass issued by the Transportation Agency of the Lamongan Regency Government. The fact that only $7.8 \%$ of fishing vessels at PPN Brondong which have boat fitting, is very alarming. The limited number of apparatus compared to the area handled is also very influential on the accuracy of the examination. So that many fishing boats without ships escaped just carrying out fishing operations. And what is not less important is the awareness of the fishermen on the importance of shipping safety so that they do not force the will regardless of the risks faced when sailing.

\section{LITERATURE REVIEW}

\section{Public Policy}

Public policy is whatever governments choose to do or not to do. Governments do many things (Trischler \& Charles, 2019). They regulate conflict within society; they organize society to carry on conflict with other societies; they distribute a great variety of symbolic rewards and material services to members of the society; and they extract money from society, most often in the form of taxes. Thus, public policies may regulate behaviour, organize bureaucracies, distribute benefits, or extract taxes-or all of these things at once (Daugbjerg \& Feindt, 2017; Dye \& Dye, 1992; Sriboonyaponrat, 2016).
Stated most simply, public policy is the sum of government activities, whether acting directly or through agents, as it has an influence on the life of citizens (Peters, 2018). Government and the policies made by the government are sometimes so controversial, frustrating, and at the same time, very important. But because the public is the source of political authority, that is, the authority to act on the public's behalf, it is clear that the government is at the centre of efforts to make public policy (Birkland, 2015; Endang \& Risal, 2017).

\section{Policy Implementation}

Most studies of policy implementation-especially in social programs such as job training, education, and health - have focused on relationships within and among large bureaucracies in which the dominant theme has often been the subtle distortion of program intent through delay and resistance by officials defending their traditional programs or responding to local resistance (Mazmanian \& Sabatier, 1983). According to Mazmanian and Sabatier (1983), there are three groups of variables that affect the success of implementation, namely the characteristics of the problem (tractability of the problems), characteristics of the policy/law (ability of statute to structure implementation) and environmental variables (no statutory variables that have implemented) (Subarsono, 2005).

\section{Analysis of the Implementation of Mazmanian and Sabatier Models}

The important role of the analysis of the implementation of state policy is to identify the variables that influence the achievement of formal objectives in the entire implementation process. The variables in question can be classified into 3 categories, namely: (1) Easy whether or not the problem is controlled, (2) Policy ability to structure the implementation process; and (3) Variables outside the law that affect implementation (Ekowati \& Roro, 2005).

\section{Shipping Safety}

In the Government Regulation of the Republic of Indonesia Number 69 of 2001 concerning Port, shipping safety is defined as a condition for fulfilling safety requirements concerning transportation in the waters and ports.

There are many causes of ship accidents because they are not heeded to the need for each vehicle onboard to be lashed to the problem of placement of goods that do not take into account the ship's centre of gravity and stable arm style. Thus, the cause of an accident of a ship cannot be stated with certainty but needs to be assessed. 
Seaworthy Certification Procedure According to the Ministry of Maritime Affairs and Fisheries (KKP)

Law No. 45 of 2009 concerning Fisheries Article 42 paragraph (3), it is explained that each fishing vessel that will sail to do fishing and/or transport fish from a fishing port must have a Sailing Permit (SIB) issued by the syahbandar at a fishing port. The Sailing Permit is issued by the syahbandar after the fishing vessel has received an operational feasibility letter (SLO) from the fisheries supervisor. In this case, the Syahbandar in question is the Syahbandar at the Port of Fisheries which is appointed by the Minister in accordance with the Decree of the Minister of Maritime Affairs and Fisheries No. 19 of 2006 concerning Appointment of Syahbandar at Fisheries Ports.

The main duty of the fishery portfolios in fishing ports (Nang \& Write, 2015): (1) Re-checking the completeness and validity of fishing vessel documents; (2) Re-checking fishing equipment on board fishing vessels; (3) Check the technical and nautical requirements of ships from aspects of shipping safety; (4) Check the requirements of the crew; (5) Regulate the departure and arrival of fishing vessels and regulate movements and traffic in fishing ports, and (6) Issue Sailing Permit (SIB) in fishing ports.

\section{METHODOLOGY}

This paper uses a descriptive qualitative approach model as the primary writing approach. The data used in this writing is secondary data, where secondary data is generally in the form of evidence, records, or historical reports that have been compiled in archives (documentary data), both published and unpublished (Moleong, 2001).

The techniques used to collect data in this paper are: (1) Study of literature; (2) Documentaries; (3) Discussion; and (4) Intuitive-Subjective, is the involvement of the author's opinion about the problem being discussed (Ghofar, 2004).

\section{RESULTS AND DISCUSSION}

Implementation of shipping safety policies at Brondong PPN was analysed using the Mazmanian and Sabatier (1983) models. According to Mazmanian and Sabatier (1983), the important role of the analysis of the implementation of state policy is to identify the variables that influence the achievement of formal objectives throughout the implementation process. The variables in question can be classified into 3 categories, namely:

\section{Easy or Not Problems Controlled Support of Theory and Technology}

In the Republic of Indonesia Law Number 17 of 2008 concerning Shipping, it is stated that shipping safety and secu- rity is a condition of fulfilling safety and security requirements concerning transportation in the sea, port, and maritime environment. Safety and security of water transport, namely the condition of compliance with the ship and navigational fitness requirements (article 117).

To ensure the safety of the shipping, fishing vessels must fulfill sea-worthy requirements. The definition of ship's sea worth according to Republic of Indonesia Law Number 17 of 2008 concerning Shipping is the condition of ships that fulfil ship safety requirements, prevention of water pollution from ships, manning, cargo lines, loading, ship crew welfare and passenger health, ship legal status, safety management and prevention of pollution from ships, and security management of ships to sail in certain waters. Ship safety as one of the requirements for the fulfillment of a ship's sea is defined as the condition of the ship that meets material, construction, building, machinery, and electrical requirements, stability, arrangement and equipment including auxiliary equipment and ship radio, electronic, as evidenced by a certificate and testing (article 1 paragraph 34 of the Republic of Indonesia Law Number 17 of 2008 concerning Shipping). The shipping safety issues that must be carried out by all fishing vessels in Brondong are very complex. The agency authorized directly in this matter is the Department of Transportation of Lamongan Regency. This agency issued a Ship Nationality Certificate (Ship) and Ship Excellence Certificate.

To obtain the Nationality Certificate (Ship Ship) has been arranged in the Lamongan Regent Decree Number 8 of 2004 concerning Retribution Measurement, Registration, Provision of Ship Nationality Certificate (Small Pass) and Ship Excellence Certificate, which requires (1) photocopy of ID card still valid, (2) Ship Ownership Letter from the local Village/Kelurahan Chief, and (3) photocopy of Ship Excellence Certificate (Lamongan Regent, 2002).

Requirements for obtaining a ship's Perfection Certificate are (1) photocopy of valid ID card, (2) photocopy of individual Establishment/identity Deed, (3) Ship Ownership Letter from local Village/Kelurahan, (4) physical data on ship building construction, (5) data on years of shipbuilding, (6) list of equipment and materials inside the ship, and (7) list of crew and crew members.

From the description above, it can be seen that the regional regulations in the form of the Lamongan Regent Decree Number 8 of 2004 do not mention ship safety equipment as a condition for obtaining the Nationality Certificate (Ship Ship) or Ship Perfection Certificate.

Technically, it is difficult to implement the safety equipment on fishing boats in Brondong. This is because the fisher- 
men's awareness of the importance of safety equipment is still low. Besides that, ship safety equipment is relatively expensive for fishermen.

A large number of fishing vessels and the vastness of the area faced with a limited number of officers is a separate obstacle in monitoring ship movements regularly. So, many fishing vessels sail without reporting to Syahbandar. And, of course, these fishing vessels sailed without Sailing Permits (SIB) issued by the Syahbandar.

It is undeniable that ship safety equipment that can guarantee the safety of shipping is high-tech, which causes the high cost of the equipment. This also becomes an obstacle for fishermen to equip their ships with ship safety equipment because they have to spend a lot of money. Not proportional to the income earned from fishing.

\section{Percentage of Total Population Covered in the Target Group}

This factor is a sub-factor of the characteristics of a fishing boat shipping program, as stated by Mazmanian and Sabatier's theories. It should be emphasized here that the clarity of the target group in the implementation of shipping safety policies on fishing vessels is very important.

The target group in the shipping safety program are the fishing communities included in the Brondong PPN work area, totaling 13,997 people with 1,546 fishing vessels Source (Food and Agriculture Organization, 2004). The fishing community is distinguished between the crew and ship owners.

One unit of fishing vessels is usually owned by several fishermen. A fisherman sometimes has several fishing vessels with the aim that if one of his ships suffers a loss, there is still a favourable expectation from other ships. They formed a group of fishermen totaling 18 Fishermen Associations.

\section{Diversity of Target Group Behaviour}

The more diverse the behaviour is regulated, or the more diverse services are given, the more difficult it is to make clear and clear rules, and thus greater freedom of action must be given to officials in the field. Given the possibility of differences in the commitment of field officials to the goals and objectives set out in policy decisions, the provision of freedom of action is likely to lead to quite fundamental differences in the success rate of program implementation.

The difference in behaviour of the target groups in addressing shipping safety policies is seen in the fishing community in Brondong. The fishing community is distinguished between the shipowner and the crew.

\section{The Desired Level of Behaviour Change}

The desired level of behaviour change in the target group is compliance with shipping safety regulations. To ensure the safety of shipping in the sea, the ship must meet the ship's seaworthiness. The standards for the feasibility of a ship's sea require that the ship to be sailing must meet the requirements of buoyancy, are movable, and feasible to navigate. The Decree of the Minister of Transportation No. KM 46 of 1996 concerning Certification of Feasibility of Fishing Vessels states that "every fishing vessel that will sail must meet the requirements for marine safety of fishing vessels and fishing vessels that are declared to meet the requirements of marine safety and Certificate of Excellence and Preservation of Fishing Vessels" (Food and Agriculture Organization, 2004).

The standards for the reliability of the ship's sea are translated differently by legislation. The following is a comparison table of marine feasibility requirements stated in the Law of the Republic of Indonesia Number 17 of 2008 concerning Shipping, Decree of the Minister of Transportation Number KM 46 of 1996 concerning Certification of Feasibility of Fishing Vessels, and definition of Unus researchers from Bogor Agricultural Institute 2004.

However, the facts in the field indicate that the level of compliance with the implementation of shipping safety policies is very low. Only $4 \%$ of all fishing vessels in Brondong have valid nationality certificates.

\section{Policy Ability to Structure the Implementation Process Clarity and Consistency of Purpose}

The shipping safety regulations for fishing vessels are affirmed by the Minister of Transportation as outlined in the Decree of the Minister of Transportation Number KM 46 of 1996 concerning Certification of the Feasibility of Fishing Vessels, which states that every Fishing Vessel which will sail must meet the requirements of the Fishing Vessel. Fishing vessels that are declared to meet the requirements for marine worthiness are given the Nationality Certificate of the Ship. The Local Government of Lamongan Regency is in accordance with its authority as stipulated in the Government Regulation of the Republic of Indonesia Number 25 Year 2000 concerning Government Authority and Provincial Authority as Autonomous Regions (Global Regulation, 2007) which is updated by Republic Government Regulation Indonesia Number 38 of 2007 concerning Division of Government Affairs Between the Government, Provincial Governments, and Regency/City Governments, has the right to handle fishing vessels with Gross Tonnage (GT) of less than 7 (Govrnment Regulation of the Republic 
of Indonesia, 2008).

Government Regulation of the Republic of Indonesia Number 25 Year 2000 concerning Government Authority and Provincial Authority as Autonomous Regions (State Gazette of the Republic of Indonesia Number 54 of 2000, Supplement to State Gazette of the Republic of Indonesia Number 3952) which is updated by Republic Government Regulation Indonesia Number 38 of 2007 concerning Division of Government Affairs Between the Government, Provincial Governments, and Regency/City Governments.

On the basis of the above regulations, Lamongan District Regulation Number 8 of 2004 concerning Retribution Measurement, Registration, Provision of Ship Nationality Certificate (Small Pass) and Ship Excellence Certificate, which states that each ship measuring gross contents is smaller than GT 7 operated on the sea or river must meet shipping safety requirements.

In order to fulfill the shipping safety requirements, each vessel measuring gross contents smaller than GT 7 must be measured, registered and equipped with the Nationality Certificate (Small Pass) and must have a Ship Perfection Certificate.

In its implementation, the Department of Transportation of Lamongan Regency as the policy implementor encountered several obstacles, including: (1) Most shipowners did not try to obtain ship fitting due to a large number of costs incurred, especially during ship measurement. Officials authorized to carry out ship measurements are personnel from Syahbandar Gersik or Syahbandar Surabaya; (2) So far, there has been almost no decisive action from law enforcement officials in the sea who have questioned the completeness of safety equipment on board. So there is no driving factor for shipowners to equip their ships with ship safety equipment; (3) Sea fishing operations that have been going on for a long time have become accustomed without the existence of safety equipment according to government regulations. Instead of a float, it is a 25 -liter empty jerry can and a hatch covered with cork. While about 10-meter long bamboo is used to help people who fall in the sea, replacing the rope function.

\section{Accuracy of Fund Source Allocation}

Mazmanian and Sabatier revealed that funds were needed at a certain threshold level to open opportunities to achieve formal objectives in order to achieve effective implementation. The accuracy of the allocation of funding sources is very important because the amount of the budget sourced from the APBN (State Budget and Expenditure) is very limited to financing the shipping safety program of fishing ves- sels.

One of the uses of the budget is for the socialization of shipping safety for fishing vessels. However, the outreach activities have not had a significant impact on fishermen's compliance with shipping safety regulations as expected. The fishermen are still reluctant to complete their ships with ship safety equipment.

\section{Integration of Inter-Institutional Hierarchy of Organi- zations}

One important feature that every good rule of law needs to have according to Mazmanian and Sabatier, is its ability to integrate the hierarchy of implementing agencies. When the ability to integrate agencies, agencies and institutions fails to be implemented, coordination between agencies that facilitates the implementation of policies will actually disperse the objectives of the policies that have been set (Agustino, 2007). The diversity of agencies implementing a program can be seen as capital in terms of human resources that must be managed in such a way that it can be a positive side of program implementation. However, when these agencies fail to be integrated, it will only become a barrier to the effective and efficient implementation of the implementation.

The authority of the two institutions mentioned above is clear and not overlapping, even supporting each other. Syahbandar can be said to be the last supervisor of the completeness of auxiliary equipment on board before the ship carries out fishing operations at sea. Thus, it can guarantee the safety of shipping. In addition, law enforcement at sea is also carried out by small units of elements of the Indonesian Navy's National Police and Posal Aquatic Police. In accordance with what is stated in the Government Regulation of the Republic of Indonesia Number 38 of 2007 concerning Division of Government Affairs between the Government, Provincial Governments, and Regency/City Governments (Global Regulation, 2007). So the Lamongan District Transportation Agency has the authority to issue Ship Nationality and Ship Perfection Certificate for GT fishing vessels $<7$.

The facts on the ground indicate that the Lamongan District Transportation Agency in coordinating with law enforcement officers in the sea, both with the Aquatic and Posal Police (TNI AL Post) in the Brondong PPN working area, is not optimal.

In addition, the Department of Transportation of Lamongan Regency is not optimal in coordinating directly with the Marine and Fisheries Service of Lamongan Regency. The shipowner, after receiving the Ship, takes him to the Lam- 
ongan Regency Marine and Fisheries Service to obtain SIPI (Fishing License), which is then based on the Ship and SIPI Pass; then, the Brondong PPN Headquarters issue SIB (Sailing License).

From the description above, it can be concluded that the integration of the hierarchy between implementing institutions is not as expected. Each Service/agency implementing agency runs on its own according to its main tasks and functions.

Going forward, although there is no overlap in authority to handle shipping and licensing safety issues, it is necessary to carry out integrated coordination. In this case, the Lamongan regent as Head of the Regional Government needs to make an agenda of coordination meeting on shipping safety involving the Department of Transportation, Maritime and Fisheries Agency, Head of Brondong PPN, Head of Brondong PPN Headquarters, Polair, Indonesian Navy, PPPNS, and Chairmen of Fishermen Pillars. Coordination meetings are scheduled at least once a month, so that developments in the field can be evaluated immediately.

\section{Implementation Rules of the Implementing Agency}

In addition to providing clarity of goal consistency, minimizing obstacles, and intensive fulfillment of the compliance of target groups, a law can still influence further the implementation process by formally outlining the decisionmaking rules of the implementing agencies.

The Decree of the Minister of Transportation Number 46 of 1996 concerning Certification of the Viability of Marine Fishing Vessels, states that:

"Every fishing vessel that will sail must meet the marine feasibility requirements of fishing vessels and fishing vessels that are declared to meet the requirements for marine worthiness to be given a letter and certificate in the form of Ship Nationality Certificate and Certificate of Excellence and Preservation of Fishing Vessels" (Articles 1 and 2).

To follow up on the Decree of the Minister of Transportation above, the Lamongan District government-issued local regulations in the form of Lamongan Regent Decree Number 11 of 2005 concerning Implementation Guidelines for Lamongan District Regulation Number 8 of 2004 concerning Retribution Measurement, Registration, Provision of Ship Nationality Certificate (Small Pass) and Ship Excellence Certificate.

The regional regulations include governing the procedure for submission and requirements for the Nationality Certificate (Small Pass) and Shipbuilding Perfection Certificate. To obtain the Nationality Certificate (Small Pass) and Ship Excellence Certificate, the shipowner must submit a written application to the Regional Head through the Head of the Transportation Agency.

The Lamongan Regency Transportation Service can receive and process applications for the Ship Nationality Certificate (Small Pass) if the requirements have been met by the applicant. The processing and issuance of the Ship Perfection Certificate must be based on field conditions and must pay close attention to shipping safety and be guided by regulations on vessel feasibility as well as legislation related to ship perfection.

\section{Recruitment of Implementing Agencies}

In principle, there are several ways that legislators/regulations can be taken to ensure that implementing officials have the agreement required to achieve the objectives. The responsibility for implementation can be assigned to agencies whose policy orientation is in line with regulations and are willing to place the program on top priority.

According to its main task, the agency that handles shipping safety issues is the Department of Transportation of Lamongan Regency and Brondong PPN Headquarters. The two implementing agencies in providing permits are always based on meeting the feasibility requirements of the ship's sea to guarantee shipping safety. An informant from the Lamongan District Transportation Agency said: "We process the ship that was submitted by the shipowner, but sometimes even though the conditions are incomplete, for example, there is no letter of measurement, we still process. The reason is to provide convenience to them ". For ship owners, obtaining a measurement letter is not an easy matter because, in addition to the problem of the cost that is not small, it must also bring a measuring officer from Syahbandar Gersik or Syahbandar Surabaya. Head of Syahbandar PPN Brondong Bro. Amik Armiyoso, A.Pi., M.Sc., said:

"We provide SIB based on evidence of the existence of SIPI and Pas Kapal from ship owners besides paying attention to weather factors". Based on the Decree of the Directorate General of Capture Fisheries No. 4356/DPT3/KF.440.D3/X/2006, one of the main duties of the fisheries portfolios in fishing ports is to examine the technical and nautical requirements of ships from aspects of shipping safety. Thus, the Shahbandar should continue to consider aspects of shipping safety in the field in providing SIB. The head of the Brondong PPN Syahbandar added: "Our human resources are very limited; it is difficult for us to monitor one by one from the thousands of ships here." From the description above, it can be seen that the executors of the shipping safety policy have not optimally implemented shipping safety regulations due to various obsta- 
cles.

\section{Outside Variables That Affect the Implementation Pro-} cess Socio-economic and Technology Conditions

The success of a program is not only determined by one factor but is determined by various factors, including the socioeconomic conditions of the community.

The level of self-help of fishermen communities in the form of cash from very small fishing communities is one of the obstacles that relate to the socio-economic conditions of the community. This condition has caused the implementation of the shipping safety program to not proceed as expected. Besides that, the socio-economic conditions of fishing communities also affect the repayment of installments on the assistance of ship safety equipment in the form of a lifejacket that is sought by the Syahbandar. The funds they receive from the results of catching fish are sometimes only enough to be used to fulfill their daily needs.

As is known that the shipping safety equipment on board generally uses high technology in its manufacture, causing prices to be relatively high. The fishing community must spend no small amount of money if they have to equip their fishing vessels with ship safety equipment.

\section{Public Support}

Public support is one of the factors outside the policy that affects the effectiveness of the implementation of shipping safety programs. This has also been discussed by Mazmanian and Sabatier.

To be able to achieve the results of policy implementation, each program also requires support from superiors both in budget allocation and protection from actors who do not support the policy.

Community support for shipping safety and facilities does not come naturally, but the needs and beliefs of the people for shipping safety and socialization are more important. In accordance with Government Regulation Number 81 of 2000 concerning Navigation where the Directorate of Navigation of the Directorate General of Sea Transportation who plays a role and is responsible for the functions of shipping safety has not been known or recognized by various parties, both government agencies and service users, but the benefits have been felt.

One of the Non-Governmental Organizations (NGOs) established for the benefit of shipping safety is the Bawean Building Movement (Gate). Abdul Basit Karim, the Gate Coordinator, once requested that the port administrator (adpel) inspect all shipping equipment for all ships on the
Gresik-Bawean route. This is related to the policy of the Gresik Port Administration which prohibits the sailing of the KMP Tri Star-9 because it is not yet equipped with a number of shipping safety requirements (Nang \& Write, 2015).

\section{Attitudes and Resources of the Target Group}

Community groups can influence the process of implementing policies, both those that support the program and those who oppose the program. There are differences in addressing shipping safety regulations in the target group. The fishermen who are crew members realize the importance of shipping safety and tend to want the completeness of safety equipment on board. But when it is asked to the shipowner, they tend to be reluctant to complete their ship with safety equipment. It is because ship safety equipment is expensive, not in accordance with income from fishing.

Thus it can be concluded that the reluctance of shipowners to equip their ships with safety equipment is due to limited financial resources. In addition, it is also due to the attention of the authorities in the sea who tend not to prioritize shipping safety issues as an important factor that must be considered in sea fishing operations.

\section{Support of Higher Officials}

According to Mazmanian and Sabatier, superior institutions of implementing agencies can provide support for the objectives of the law through the number and direction of supervision, the provision of financial resources, the number of new tasks that conflict with the old tasks.

In the context of smooth traffic in the sea and river waters and for shipping safety, the Local Government of Lamongan Regency regulates, controls and controls ship operations in the waters through Regent Decree Number 8 of 2004 concerning Retribution Measurement, Registration, Provision of Ship Nationality Certificate (Small Fitting) and Certificate of Ship Perfection.

\section{Target Compliance To Comply With Output}

The policy steps taken by the Department of Transportation of Lamongan Regency have not been effective. Facts on the ground indicate that the facilities provided by the Department of Transportation of Lamongan Regency have not been utilized properly by fishermen/shipowners. Until 2010, only $4 \%$ of the total fishing vessels (1,546 units) in Brondong, which had the Nationality Certificate (Pas Kapal), were still active. 


\section{Impact of Output of Shipping Safety Policy}

The policies taken by the Lamongan District Transportation Agency have two effects, positive and negative. Positive impacts for fishermen/shipowners are: (1) Pressing the cost of the Ship Perfection Certificate management, especially when measuring vessels, which must bring a measuring officer from Syahbandar Gersik or Syahbandar Surabaya; and (2) Fishermen/owners are easier to administer the Nationality Certificate (ship fitting) because they do not have to go to the East Java Province Transportation Agency, which is quite far but sufficient at the Lamongan District Transportation Agency.

The negative impact is that fishermen have difficulties when entering fishing ports outside Brondong, for example Gersik or Surabaya. The port syahbandar clerk knew that the boat fitting shown by Brondong fishermen did not match the actual size of the ship.

\section{Revision of the Law}

The implementation of shipping safety policies for fishing vessels can be carried out effectively if it is based on a clear and firm legal umbrella. From the results of the study, the regulations that need to be revised are (1) Decree of the Minister of Transportation Number KM 46 of 1996, revised with reference to the Law of the Republic of Indonesia Number 17 of 2008 concerning Shipping; and (2) Lamongan Regent Decree Number 11 of 2005 concerning Implementation Guidelines for Lamongan District Regulation Number 8 of 2004 concerning Retribution Measurement, Registration, Ship Nationality Letter (Small Pass) and Ship Excellence Certificate, revised by specifying specifically the ship's safety equipment as conditions for obtaining a Ship Perfection Letter.

With the revision of the regulation above, it will be used as a guideline for implementing agencies and minimizing discretion so that the objectives of the fishing vessel shipping policy can be achieved.

\section{Factors Affecting the Implementation of Safety Policy for Shipping of Fishing Vessels at Brondong Nusantara Fisheries Port, Lamongan, East Java}

The implementation of the fishing vessel safety policy in Brondong is very complex. Many factors influence it so far, even though various shipping safety regulations have been issued at the central government level, ministerial level to the local government level as if unable to change the behaviour and attitudes of fishermen on shipping safety in carrying out fishing operations at sea.
The stubbornness of the fishermen who ignore the completeness of ship safety in fishing operations at sea is due to the too loosening of policy discretion from implementing agencies in implementing existing regulations. Too much discretion is possible due to the lack of strict regional regulations in regulating shipping safety issues. There are still loopholes from the regulation that can be breached by the implementing agency not to enforce the regional regulations strictly.

In paragraph 2 article 5 Lamongan Regent Decree Number 11 of 2005 concerning Implementation Guidelines for Lamongan District Regulation Number 8 of 2004 concerning Retribution Measurement, Registration, Ship Nationality Certificate (Small Pass) and Ship Excellence Certificate, does not explicitly require the existence of completeness ship safety must be on board to obtain the Nationality Certificate (Small Pass) and Ship Perfection Certificate. Shipping safety factors are mentioned in paragraph 2 , article 6 , namely:

"Processing and issuance of Ship Perfection Certificates must be based on field conditions and must pay close attention to shipping safety and be guided by regulations on vessel feasibility and laws and regulations related to ship perfection."

With no detailed mention of safety equipment that must be on board as a condition for the feasibility of a ship's sea, the implementing agency can more freely take a discretionary policy in processing and issuing Shipbuilding Perfection and Shipbuilding Certificates. Other factors that influence the implementation of shipping policies are the steps taken by Syahbandar PPN Brondong in the granting of SIB. Based on the Decree of the Directorate General of Capture Fisheries No.4356 DPT3/KF.440.D3/X/2006, one of the main duties of the fisheries portfolios in fishing ports is to examine the technical and nautical requirements of ships from aspects of shipping safety. But because the number of $\mathrm{Hu}-$ man Resources is limited compared to the thousands of fishing vessels, it cannot be carried out optimally. So, the provision of SIB is only based on the ownership of SIPI and Pas Kecil other than, of course, the weather factor in the sea. The role of law enforcement officers at sea is also very influential in the implementation of shipping safety policies. So far, law enforcement officers in the sea tend not to pay attention to the problem of the completeness of safety equipment on the ship. What is always asked of fishermen is the ownership of SIPI so that if there is a boat that violates the fishing area, it will be dealt with firmly. When the ship was almost never inspected, it was understandable if an informant said that the ship's pass was never extended because 
it was forgotten, even when the ship was never opened. Coordination between weak implementing agencies is also an obstacle in the implementation of shipping safety policies. During this time, almost never carried out integrated coordination between the Department of Transportation Lamongan, Lamongan Regency Marine and Fisheries Service, Brondong PPN, Brondong PPN Syahbandar, and law enforcement officers in the sea (PPPNS/Civil Servants Officer, Polair/Indonesian Water Police and Indonesian Navy). For the fishermen, the most serious factor in addressing shipping safety regulations is that they consider the existence of safety equipment on board as unimportant. Hereditary traditions have taken root in their hearts that objects on board are objects that float in water so that they can be used as a helper when accidents occur at sea. In addition, ship safety equipment is felt to be expensive compared to income from fishing.

Another factor that causes the fishermen to be reluctant to take care of the ship's pass is the requirement for measuring letters. The authorized measuring officer is from the Gersik and Surabaya syahbandar. This causes an increase in the cost of the ship owner's costs.

Given the information above, it can be concluded that fishermen's awareness of the importance of ship safety equipment is very low. There must be law enforcement measures so that the implementation of shipping safety policies is carried out as expected.

\section{CONCLUSION}

Based on the results of research and discussion, it can be concluded that the implementation of the safety policy of fishing vessels shipping at the Brondong Archipelago Fisheries Port (PPN) in Lamongan Regency, East Java is difficult to implement due to several obstacles, including:

1. Support theory and technology: (a) Decree of the Minister of Transportation Number 46 of 1996 concerning Certification of Feasibility of Marine Fishing Vessels still refers to the Law of the Republic of Indonesia Number 21 Year 1992 concerning Shipping, which does not explicitly state the fulfillment of the requirements of equipment for assistance (tools safety) on the boat; (b) Regional regulations in the form of the Lamongan Regent Decree Number 8 of 2004 do not specify ship safety equipment as a condition for obtaining the Nationality Certificate (Ship Ship) or Shipbuilding Perfection Certificate; and (c) The high cost of ship safety equipment is caused by the high technology used in the manufacture.

2. Diversity of behavior of the target group. The presumption of most fishermen is that fishing vessels and their parts are made of materials that can float so that they can be used as a helper.

3. The desired level of behavior change. Low awareness of fishermen to comply with shipping safety regulations.

The factors that influence the implementation of fishing vessel shipping safety policies at the Brondong Nusantara Fisheries Port, Lamongan, East Java are:

1. Accurate allocation of funding sources. The routine budget provided to the implementing agency is not sufficient to implement a shipping safety program.

2. Integrated hierarchy between implementing agencies. The integration of the hierarchy between implementing institutions is not as expected due to a lack of coordination. Each agency/agency implementing agency runs on its own according to its main tasks and functions.

3. Socio-economic and technological conditions. As is known that the shipping safety equipment on board generally uses high technology in its manufacture, causing prices to be relatively high. The fishing community must spend no small amount of money if they have to equip their fishing vessels with ship safety equipment.

\section{LIMITATIONS AND RECOMMENDATIONS}

Following are the limitations and suggestions given to overcome the issues:

1. Support theory and technology. There needs to be a revision of laws and regulations that focus on shipping safety, namely: (a) Decree of the Minister of Transportation Number 46 of 1996 concerning Certification of Feasibility of Fishing Vessels, revised referring to the Laws of the Republic of Indonesia Number 17 of 2008 concerning Shipping; (b) Lamongan Regent Decree Number 11 of 2005 concerning Implementation Guidelines for Lamongan District Regulation Number 8 of 2004 concerning Retribution Measurement, Registration, Granting of Ship Nationality Letter (Small Fitting) and Ship Excellence Certificate, revised by specifying specifically ship safety equipment as a condition obtain Ship Perfection Letter; and (c) Providing subsidies in the procurement of safety equipment by the government.

2. Diversity of behaviour of the target group. Provide detailed explanations of ship safety equipment to eliminate the perception of fishermen/shipowners that safety equipment is merely identical to objects that can float.

3 . The desired level of behaviour change. Carry out socialization of safety of continuous shipping tirelessly to fishermen and ship owners so that awareness arises to comply with regulations.

The factors that influence the implementation of the fishing vessel shipping safety policy are sought to be a driver of 
the implementation of shipping safety programs; it is recommended:

1. Accurate allocation of funding sources. To overcome the limited source of funds can be taken through (a) Using the existing budget to implement shipping safety programs efficiently; and (b) Increase the budget sourced from the State Budget (Budget and State Expenditures) and the Regional Budget (Regional Budget) of Lamongan Regency.

2. Integrated hierarchy between implementing agencies.
An initiative from the implementing agency supervisor is needed to improve coordination so that the shipping safety program can be achieved.

3. Socio-economic and technological conditions. There needs to be an initiative from the Lamongan Regent to empower large-scale Corporate Social Responsibility (CSR) programs in the Lamongan Regency area, which are directed to assisting the availability of ship safety equipment for fishermen.

\section{REFERENCES}

Agustino, L. (2007). Perihal ilmu politik: Sebuah bahasan memahami ilmu politik. Bandung, Indonesia: Graha Ilmu.

Birkland, T. A. (2015). An introduction to the policy process: Theories, concepts, and models of public policy making. New York, NY: Routledge.

Chan, S. R., Hamid, N. A., \& Mokhtar, K. (2016). A theoretical review of human error in maritime accidents. Advanced Science Letters, 22(9), 2109-2112. doi:https://doi.org/10.1166/asl.2016.7058

Daugbjerg, C., \& Feindt, P. H. (2017). Post-exceptionalism in public policy: transforming food and agricultural policy. Journal of European Public Policy, 24(11), 1565-1584. doi:https://doi.org/10.1080/13501763.2017.1334081

Department of Transportation of Lamongan District. (2018). Weather data environment. Retrieved from https://bit.ly/ $2 \mathrm{UbhrBr}$

Dye, T. R., \& Dye, T. R. (1992). Understanding public policy. Englewood Cliffs, NJ: Prentice Hall.

Ekowati, M. R. L., \& Roro, M. (2005). Perencanaan, implementasi dan evaluasi kebijakan atau program. Surakarta, Indonesia: Pustaka Cakra.

Endang, K., \& Risal. (2017). The effect of investment decision financing decision dividend payment policy and company size. Journal of Administrative and Business Studies, 3(2), 105-113. doi:https://doi.org/10.20474/jabs-3.2.5

Food and Agriculture Organization. (2004). Fisheries. Retrieved from https://bit.1y/3aVLiDS

Ghofar, A. (2004). The sape strait cephalopod resource and its response to climate variability. Journal of Coastal Development, $8(1), 35-45$.

Global Regulation. (2007). Government regulation number 38 of 2007. Retrieved from https://bit. ly/2S5BGOH

Govrnment Regulation of the Republic of Indonesia. (2008). Disater managment. Retrieved from https ://bit. ly/2vCDnLE

Lamongan Regent. (2002). Regulation of 27 June 2002 no. 754 concerning ship's name, call sign and home port. Retrieved from https://bit.1y/31a0vNb

Mazmanian, D. A., \& Sabatier, P. A. (1983). Implementation and public policy. Glenview, IL: Scott Foresman.

Moleong, L. J. (2001). Metode penelitian kualitatif. Bandung, Indonesia: PT Remaja Rosdakarya.

Nang, D., \& Write, S. (2015). Socio-economics of trawl fisheries in Southeast Asia and Papua New Guinea. In Proceedings of the Regional Workshop on Trawl Fisheries Socio-Economics, Chaam, Thailand (Vol. 26).

Peters, B. G. (2018). American public policy: Promise and performance. Cambridge, MA: CQ Press.

Sriboonyaponrat, P. (2016). The implementation process of the public policy to promote and develop the quality of life of the disabled in Thailand. International Journal of Humanities, Arts and Social Sciences, 2(6), 198-202. doi:https:// doi.org/10.20469/ijhss.2.20001-6

Subarsono, A. (2005). Analisis kebijakan publik: Konsep, teori dan aplikasi. Jakarta, Indonesia: Pustaka Pelajar.

Trischler, J., \& Charles, M. (2019). The application of a service ecosystems lens to public policy analysis and design: Exploring the frontiers. Journal of Public Policy \& Marketing, 38(1), 19-35. doi:https://doi.org/10.1177/0743915618818566 